\title{
ZCO/CNT Composites Coated on Silver Substrates as Symmetric Supercapacitor and their Dielectrics Characterization at Various Frequencies
}

\author{
Markus Diantoro ${ }^{1}$, Lisa Ainun Najihah ${ }^{1}$, Ahmad Taufiq $^{1}$, Abdulloh Fuad $^{1}$, \\ Arif Hidayat $^{1}$, Subakti ${ }^{1,2}$ \\ ${ }^{1}$ Department of Physics, Central Laboratory Faculty of Mathematics and Natural Sciences, \\ University of Malang. Jl. Semarang 5 Malang 65145 \\ ${ }^{2}$ Universidad Complutense de Madrid, Spain \\ m_diantoro@yahoo.com
}

Received 08-01-2014, Revised 22-04-2014, Accepted 25-04-2014, Published 30-04-2014

\begin{abstract}
Supercapacitor is a high power density energy storage device which complements the lack of batteries and conventional capacitors. One material which has a great potential in the manufacture of composite supercapacitor is spinel $\mathrm{ZnCo}_{2} \mathrm{O}_{4} /$ carbon nano tube and abreviated in the later case as $\mathrm{ZCO} / \mathrm{CNT}$. Composition variations in $\mathrm{ZCO} / \mathrm{CNT}$ composites is expected to the performance of supercapacitor especially the dielectric properties and specific capacitance. In this study the composite $\mathrm{ZCO} / \mathrm{CNT}$ was made from raw materials of ZCO nano crystal which was prepared from previous research on which employing sonochemistry technic, carbon nano tube, and 1-methil 2 pyrolidine. A screen printing method was used in this experiment to deposite the composite on silver substrates. The separator in between of two identical composite structures was prepared from isotactic polypropylene. We used KOH $6 \mathrm{M}$ which was implemented as electrolyte of the composites. Characterization of composite structures has been performed using X-RD, while the morphology characterization using SEM. It was found that the dielectric supercapacitor increase by increasing of mass fraction of ZCO in the composite. The highest dielectric constant is reached at $1.89 \times 10^{6}$ and the specific capacitance of $81 \mathrm{~F} / \mathrm{g}$ for $3: 1$ mass ratio of ZCO : CNT at $100 \mathrm{~Hz}$.
\end{abstract}

Keywords: composite ZCO/CNT, electrolyte, symmetric supercapacitor, dielectricity, frequencies.

ABSTRAK

Superkapasitor merupakan piranti penyimpan energi yang memiliki rapat energi yang besar. Superkapasitor melengkapi kekurangan yang ada pada baterei dan kapasitor konvensional. Salah satu material yang memiliki potensial yang besar dalam pengembangan komposit superkapasitor adalah spinel $\mathrm{ZnCo}_{2} \mathrm{O}_{4} /$ carbon nano tube (CNT) yang disingkat $\mathrm{ZCO} / \mathrm{CNT}$. Variasi komposisi rasio komposit $\mathrm{ZCO} / \mathrm{CNT}$ diharapkan meningkatkan performa superkapasitor khususnya pada sifat dielektrik dan kapasitansi spesifiknya. Dalam kajian ini ZCO/CNT telah difabrikasi dari bahan awal nano kristal ZCO yang disintesis dari penelitian sebelumnya dengan memanfaatkan teknik sonokimia. Bahan lain adalah CNT, dan 1-methil 2 pyrolidine. Metode screen printing telah digunakan untuk mendeposisi komposit tersebut pada substrat perak. Superkapasitor difabrikasi dengan dua buah film komposit/perak simetrik menggunakan polipropilen sebagai pemisah. Elektrolit $\mathrm{KOH} 6 \mathrm{M}$ diimplementasikan pada komposit. Karakterisasi struktur kristal pada satu sisi film digunakan X-RD, sedangkan morfologi mikro digunakan SEM. Hasil analisis menunjukkan bahwa dielektrisitas superkapasitor meningkat dengan peningkatan ratio massa ZCO pada komposit. Konstanta dielektrisitas tertinggi adalah $1,89 \times 10^{6}$ dan kapasitansi spesifik sebesar $81 \mathrm{~F} / \mathrm{g}$ untuk 3:1 rasio massa ZCO : CNT pada $100 \mathrm{~Hz}$. 


\section{INTRODUCTION}

Supercapacitors or electrochemical capacitors are a high density electrical power storage device which complements disadvantages of batteries and conventional capacitors ${ }^{[1]}$. Supercapacitors have several advantages over conventional batteries and capacitors, such as longer life spans, simple working principle and model, short charging time, safe and have a high power density ${ }^{[2-4]}$. Because of its superiority, supercapacitors have wide applications in technology that is used as a store of electrical energy in a small size on electronic equipment ${ }^{[4-6]}$.

A current great candidate material for super capacitor is $\mathrm{ZnCo}_{2} \mathrm{O}_{4}$ (ZCO) nano material composited with carbon nano tube $(\mathrm{CNT})^{[3]}$. Nano crystal ZCO have semiconducting properties at room temperature. While CNT have wide applications particularly in manufacturing electrical energy storage applications. A very small distance coupled with a very broad surface of CNTs, will produce in the ability of a very large capacity compare to the capacitor that currently exists ${ }^{[6]}$.

Supercapacitor consists of two electrodes which can be from polarized material, separator, and an electrolyte. Both electrodes are made of activated carbon having a large surface area. The ZCO provides for ongoing electrolyte ions on the redox reaction of the metal oxide layer through the mechanism of electrosorption ${ }^{[7-8]}$.

It has been reported a symmetric supercapacitor based on ZCO/CNT-stainless steel by Karthikeyan ${ }^{[3]}$ with mass ratio of $1: 1$ of CNT: ZCO. It was found that the maximum specific capacitance was obtained at a scan rate of $5 \mathrm{mV} / \mathrm{s}$. In addition to the high value of specific capacitance achieved, this system performed also a low impedance, long life time, and high coloumbic efficiency ${ }^{[3]}$.

So far, there is no detail information about the influence of mass ratio as well as frequency on dielectric properties of supercapacitors. In this works we report the fabrication and the physical characterization of symmetric supercapacitor using composite of $\mathrm{ZCO} / \mathrm{CNT}$ on silver substrate.

\section{METHOD}

We used ZCO and CNT from the previous work ${ }^{[9]}$. Basic procedure of supercapacitor preparation was modified from previous work ${ }^{[10-12]}$. The composites were prepared from ZCO and CNT powders, with the same total mass at various fraction of ZCO : CNT composition. The powders then mixed in the solvent 1-dropped methyl 2 pyrolidine with the same volume to produce a composite with the same viscosity. The composites stirred for 15 hours to obtained homogenous solution for coating technic. Coating was performed by means of screen printing on silver substrate. The wet film was then subsequently heat treated at $200{ }^{\circ} \mathrm{C}$ for $30 \mathrm{mins}$, and then etched with $6 \mathrm{M} \mathrm{KOH}$ as electrolyte.

The crystal structures of ZCO/CNT-Ag film were characterized using $\mathrm{Cu}-\mathrm{K} \alpha \mathrm{XRD}$. The morphology of one side film as well as the symmetric supercapacitor structure was examined by SEM technic. The two symmetric faces were sandwiching using a thin separator of polypropylene with a thickness of $0.05 \mathrm{~mm}$ to produce the final symmetric supercapacitor structure system as shown in Figure 1. A dc resistance and of frequency dependent of dielectric constant were employed to the samples. 


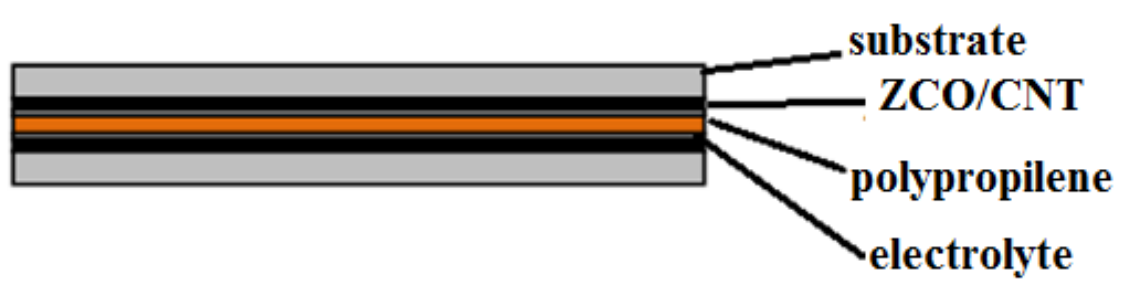

Figure 1. (color online) A sandwich structure of $\mathrm{ZCO} / \mathrm{CNT}$ based symmetric supercapacitor

\section{RESULTS AND DISCUSSION}

A result of typical XRD pattern of one side of ZCO/CNT-Ag with mass ratio of $1: 1$ is presented in Figure 2. Due to the film structure is actually consist of nano material ZCO, CNT as well as the silver substrate, we observed that strongest peaks dominated by the substrate indicated by $(\bullet)$. Albeit the peaks of ZCO indicated by $(\star)$ show less strong, there are more peaks exist in the pattern. In addition, the ZCO peaks are wide which indicates a small crystalline size. Other weak peaks belong to CNT indicated by ( $\mathbf{\square})$.

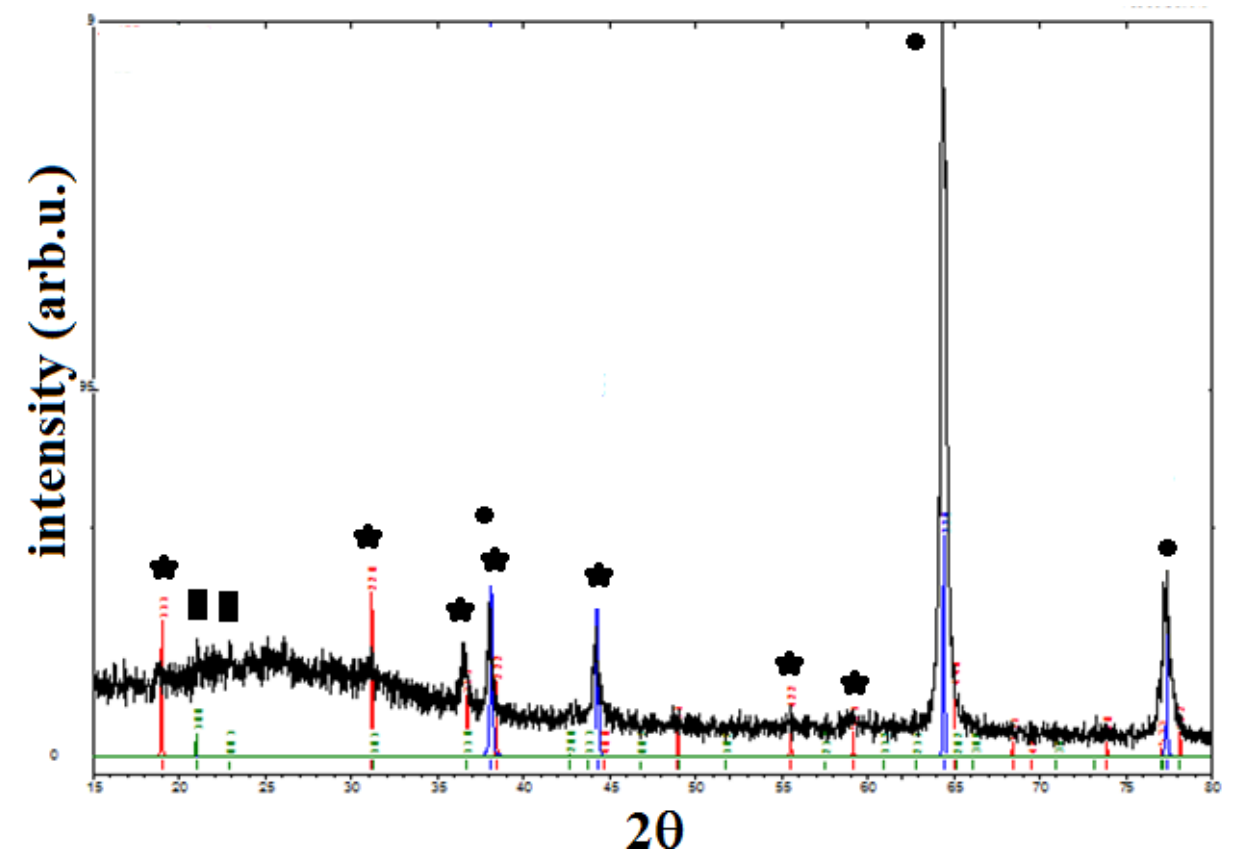

Figure 2. (color online) XRD pattern of $\mathrm{ZCO} / \mathrm{CNT}$ structure with mass ratio of 1:1

It appears that some high peaks in the diffraction pattern are oroginated from silver substrate of the composites. In order to calculate the agregate crystal size of ZCO we took the highest peak of (311) interplanar spacing using Scherrer formula. It was found that the average crystal size is $25.79 \mathrm{~nm}$. Although the method, data, and the acuracy is different, it is wise to compare the result with individual examination of ZCO grain from SEM images. A typical SEM images of the sample is shown in Figure 3. 


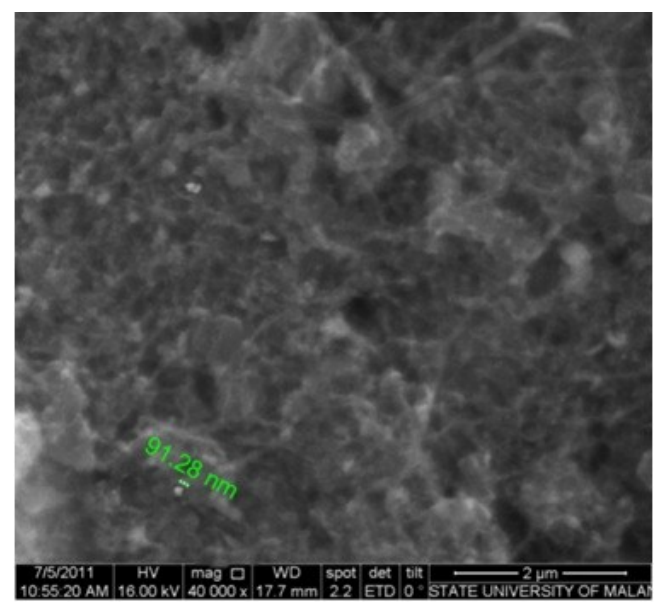

Figure 3. (color online) A typical SEM image of composite layers. Figures indicated size of the grain

SEM photo shows the typical composite grain size of $91.28 \mathrm{~nm}$ which is higher than obtained from X-RD. Although we have introduced 1-methyl-2 pyrolidine, it is found that the higher the mass fraction of CNTs in composites, the more agglomerate take place in composite. The agglomerating existence certainly affects to the supercapacitor performance because it will reduce the surface area of composite and resulted to reducing capacitance of supercapacitor.

The starting elemental composition of nano particles $\mathrm{ZCO}$ has the atomic ratio of $\mathrm{Zn}$ : Co: $\mathrm{O}$ is $1: 2: 4$. After having several chemical and physical treatment processes we found that the final atomic rasio fall to $2.84: 5.95: 14.94$ or simply by $1: 2: 5.3$. Table 1 is the data of atomic proportion of ZCO which was determined by means of SEM-EDAX equipment.

Tabel 1. Elemental composition of ZCO composite

\begin{tabular}{lll}
\hline Element & Wt \% & At \% \\
\hline C K & 48.26 & 74.56 \\
O K & 12.88 & 14.94 \\
Ag L & 09.93 & 01.71 \\
Co K & 18.91 & 05.95 \\
Zn K & 10.02 & 02.84 \\
\hline
\end{tabular}

It appears that the percentage of oxygen atoms in the compound $\mathrm{ZCO}$ is greater than expected. This is probably caused by mixing the composite $\mathrm{ZCO} / \mathrm{CNT}$ with the solvent 1 methyl-2 pyrolidine which has a molecular formula of $\mathrm{C}_{5} \mathrm{H}_{9} \mathrm{NO}$ after heating process. In the case of composite $\mathrm{ZCO} / \mathrm{CNT}$ with a ratio of 1:1after mixed with the solvent and subsequent annealed, the mass ratio ZCO and CNT recorded as simply $1: 1.15$ a bit excess in carbon. The case may originated from the carbon content in the 1-methyl-2 pyrolidine $\left(\mathrm{C}_{5} \mathrm{H}_{9} \mathrm{NO}\right)$ solvent.

Dielectric constant and resistivity as a function of mass ratio of ZCO:CNT is shown in Figure 4. The data was collected at $100 \mathrm{~Hz}$. The observed data designated as symbols while the lines are guided to the eyes. 


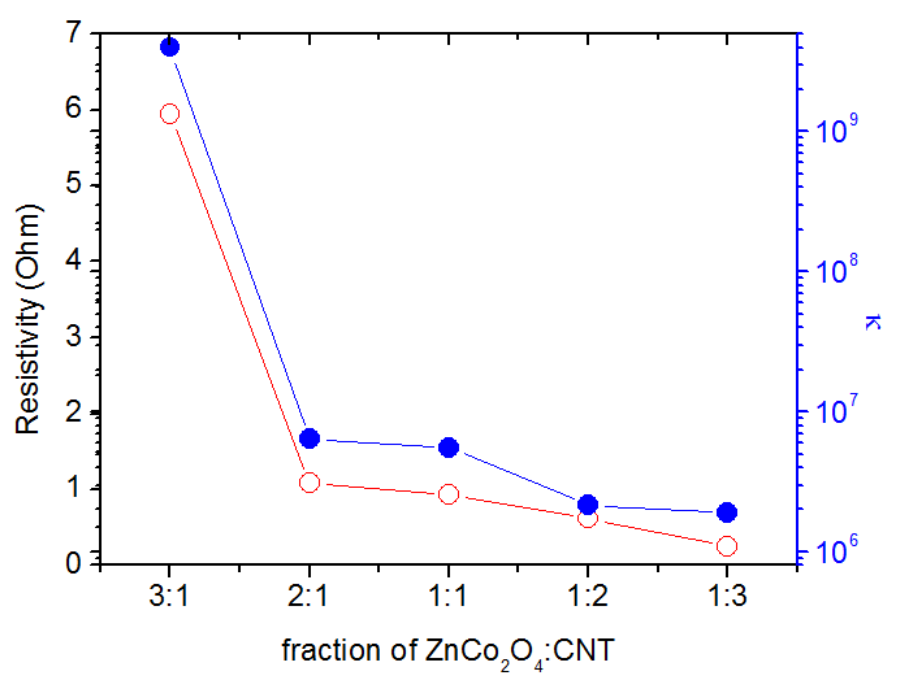

Figure 4. (color online) Resisitivity and dielectric constant of $\mathrm{ZCO} / \mathrm{CNT}$ as a function of CNT fraction

So far it appears that the dielectric properties and resistivity of ZCO/CNT-Ag supercapacitor depends on the mass fraction of each constituent of composite materials, namely the mass ZCO in CNTs. The data tell us that the decrease in mass fraction or decreasing ZCO fraction give rise to lowering resistivity. Decrease in resistivity or in other words increasing the conductivity of the composite ZCO / CNT is well expected. As ZCO reduce, CNT increase resulted to increase conductivity due to conductivity CNT. It is known that ZCO are semiconductors at room temperature, and has a high resistivity, while the CNT is a material having high conductivity.

The highest dielectric constant was reached at $4.00 \times 10^{9}$ by ZCO mass ratio of $3: 1$. On the other hand, the dielectric decreased significantly with decreasing ZCO mass fraction in the composite. The lowest dielectric constant was achieved by ratio of $1: 3$ which is most conductive as highest content of CNT. Besides nature of each constituent composite material, decreasing of the dielectric constant due to the increasing mass fraction of CNTs may also be caused by the low specific area due to the agglomeration of CNT composites after mixed in 1-methyl-2 pyrolidine solvent. The latest may give rise to suppress the role of the surface area of CNTs as composite enhancer which is apparently did not work well.

To determine the effect of frequency on the magnitude of the dielectric constant of supercapacitor, each sample was measured by the frequency range $100 \mathrm{~Hz}$ to $200 \mathrm{kHz}$. Dielectric constant of each variation compositions $\mathrm{ZCO} / \mathrm{CNT}$ for various frequencies is shown in Figure 5. 


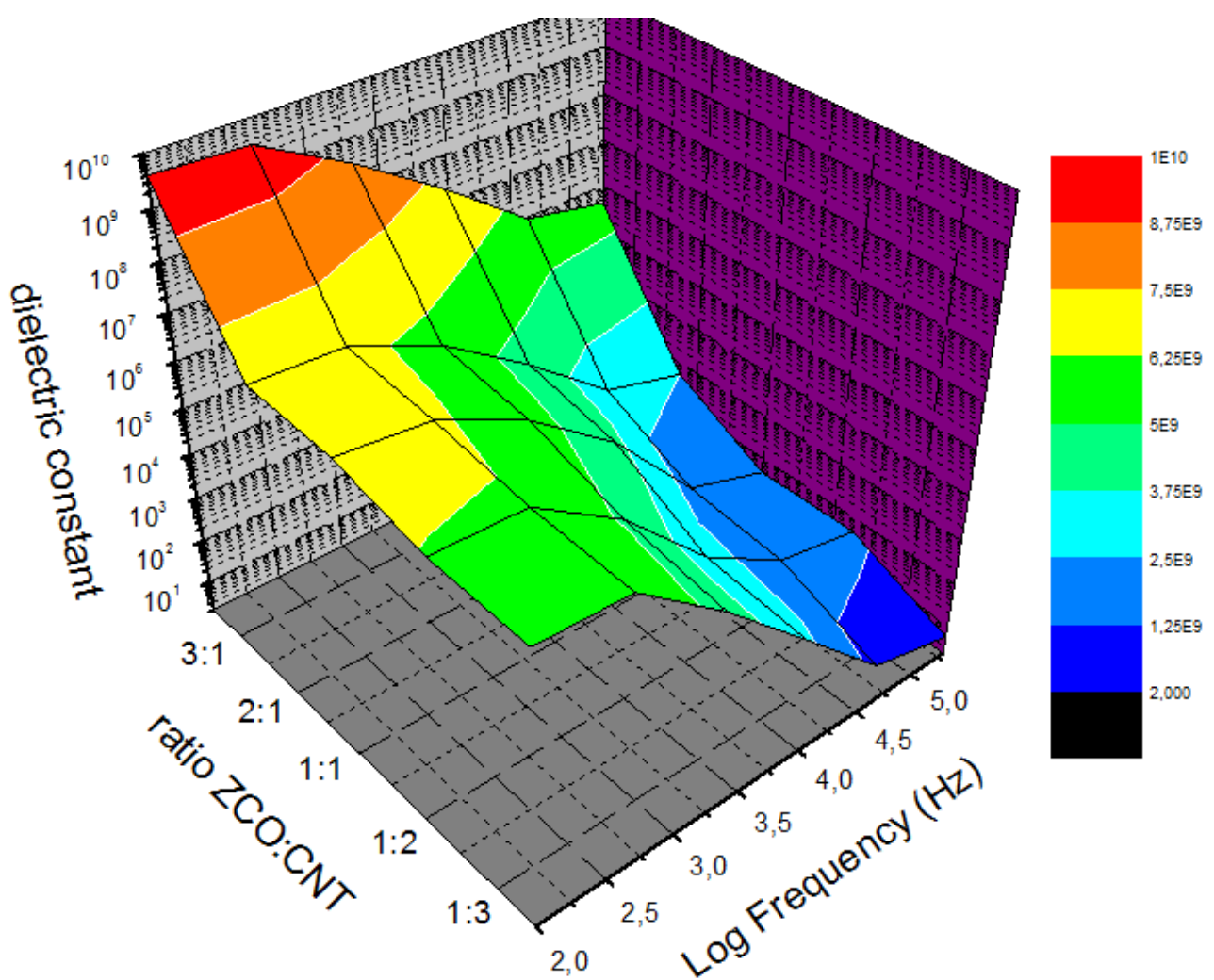

Figure 5. (color online) A $3 \mathrm{D}$ graph of dielectric constant as a function of ZCO:CNT fraction at various frequencies.

As shown in Figure 6, the highest dielectric constant of $4.00 \times 10^{9}$ and the specific capacitance of $81 \mathrm{~F} / \mathrm{g}$ were obtained by 1:3 at $100 \mathrm{~Hz}$. Albeit a different technic has been used, this value is well above what reported by Karthikeyan ${ }^{[3]}$. It is also shown that for all range of mass ratio the dielectric constant is decreasing by increasing frequency.

The origin of decreasing dielectric constant may be promoted by polarization mechanisms ${ }^{[13]}$. In the measurement range $100 \mathrm{~Hz}-200 \mathrm{kHz}$, the mechanism of polarization that occur is the polarization of the space charge where the real value of permittivity and its imaginary part decreases with increasing frequency ${ }^{[10]}$. When applied to a very high frequency oscillations of the electrons are not able to follow the fluctuations of the applied fields ${ }^{[12-13]}$.

Decrease in specific capacitance due to lower mass fraction ZCO, most likely caused by a contribution to the decrease in metal oxide dielectric and also to the decrease in redox reactions occurring at the electrode layer. Storage of electrical charge through the mechanism of redox reactions is also called the pseudo capacitance. Theoretically, the greater the surface area of the composite at supercapacitor promoted by the CNT, the greater the specific capacitance. However, the agglomeration in the electrode layer reduces the capacitance which was supported also by greater separation distance in supercapacitor. With increasing dielectricity and redox reactions generated by the metal oxide ZCO may increase the specific capacitance.

\section{CONCLUSION}

It is found that increase of the mass fraction of ZCO in the composite give rise to increase the resistivity as well as the dielectric constant of symmetric supercapacitor. It was shown that ZCO has an important role in increasing the dielectric constant. Highly surface area and conductive nature of CNTs did not contribute in the mechanism of increasing dielectric 
constant as well as the specific capacitance. The samples showed that increasing frequency tends to lower dielectric constant of supercapacitor.

\section{ACKNOWLEDGEMENT}

Part of this work was partially supported by Dikti through National Strategies Research Grant.

\section{REFERENCES}

1. Gui-Xin, W., Bo-Lan, Z., Zhuo-Log, Y. and Mei-Zhen, Q. 2004. Manganese Oxide/ MWNTs Composites Electrode for Supercapacitor. Solid State Ionics, Vol. 176, pp. 1169-1174.

2. Kay, H.A., Won, S.K., Young, S.P., Jeong-Mi, M., Dong, J.B., Seong, C.L., Young, S.L. and Young, H.L. 2001. Electrochemical Properties of High-Power Supercapacitors Using Single-Walled Carbon Nanotube Electrodes. Advanced Functional Materials, Vol.11, pp. 387-392.

3. Karthikeyan, K., Kalpana, D. and Ranganathan, N.G. 2009. Synthesis and Characterization of $\mathrm{ZnCo}_{2} \mathrm{O}_{4}$ Nanomaterial for Symmetric Supercapacitor Aplication. Ionics, Vol. 15, pp. 107-110

4. Jayalakshmi, M. and Balasubramanian, K. 2008. Simple Capacitor to Supercapacitor, An Overview. Int. J. Electrochem. Sci., Vol. 3, pp. 1196-1217.

5. Sahay, K. and Dwivedi, B. 2009. Supercapacitor Energy Storage System for Power Quality Improvement : An Overview, J. Electrical Systems, Vol. X, pp. 1-8

6. Thomas, J. B., David, A. E., Jay, L. G. and Alan, B. M. Nonaqueous Electrical Storage Device, US 5973913 A

7. Holister, P. and Harper, T.E. 2002. The Nano Technology Opportunity. University of Montreal. Canada.

8. Kushnir, D. 2007. A Technology Assessment of Carbon Nanoparticles: Production Energy Requirements and Implications for Use. Thesis, Chalmers University of Technology, Sweden.

9. Diantoro, M. and Subakti, N. 2009. Pengembangan Bahan Nanomaterial ZnCo2O4/Carbon Nanotube (CNT) untuk Aplikasi Energy Storage dan Sel Baterei Superkapasitor Simetrik, Research Report, Reasearch Board, State University of Malang, un-published.

10. Sharma, Y., Sharma, N., Subba Rao, G.V. and Chowdari, B.V.R. 2007. Nanophase $\mathrm{ZnCo}_{2} \mathrm{O}_{4}$ as a High Performance Anode Material for Li-Ion Batteries. Adv. Funct. Mater., Vol. 17, pp. 2855-2861.

11. Bazuev, G.V., Gyrdasova, O.I., Grigorov, I.G. and Koryakova. O.V. 2005. Preparation of $\mathrm{ZnCo}_{2} \mathrm{O}_{4}$ Spinel Whiskers from Zinc Cobalt Oxalate. Inorganic Materials, Vol. 41, pp. 288-292.

12. Hone, J., Liaguno, M.C., Biercuk, M.J., Johnson, A.T., Batlogg, B. and Fischer, J.E. 2004. Thermal Properties of Carbon Nanotubes and Nanotube-Based Materials, Appl. Phys. A, Vol. 74, pp. 339-343.

13. Newham, R.E. 2005. Properties of Material. New York: Oxford University Press. 